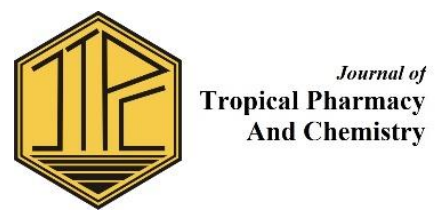

\title{
Review of Natural Remedies for Accelerate Diabetic Wound Healing
}

\author{
Rr. Kirana Andranilla, Yasmiwar Susilawati \\ Apotechary Department, Faculty of Pharmacy, \\ Universitas Padjadjaran \\ J1. Raya Bandung, Sumedang Km 21 Jatinangor 45363 \\ Email: kiranaandranilla@gmail.com
}

\begin{abstract}
Diabetic is a metabolic disorder disease leading to hyperglycemia because of lack of insulin secretion or inadequate of insulin activity. Indonesia has 9.600 plant species that have been used for health care and treatment of various diseases. Diabetic patients can experience a problem in the form of foot blood vessels disorders and if not treated properly will become wounds that are difficult to heal and easily develop into gangrene which is high risk of amputation. Therefore, this journal will discuss natural remedies that can be used as a treatment in patients with diabetic wounds and several pharmacological testing performed for testing the diabetic wound healing activity. Various kinds of natural remedies such as Andredera cordifolia, Centella asiatica, Curcuma longa, Carica papaya and hone are proven to accelerate diabetic wound healing through various mechanisms.
\end{abstract}

Keywords: diabetic, diabetic wound, natural remedies

$$
\text { Submitted on: 27 July } 2018 \quad \text { Accepted on: 30 July } 2018
$$

DOI: https://doi.org/10.25026/jtpc.v4i3.182

\section{INTRODUCTION}

Diabetes mellitus is a metabolic disorder that appears in a person and characterized by elevated blood glucose level (hyperglycemia) [1] because of insulin secretion, insulin activity or both are inadequate [2].

Some Indonesian suffering from diabetes mellitus in 2000 reached 8.43 million people [3], and it will increase to 333 million people in 2025 [4]. Diabetics can experience one problem of foot blood vessel disorders and if it is not treated properly will easily get injured and develop into gangrene which is at high risk for amputation [5]. The risk of amputation is $15-40$ times more frequent in DM patients compared to non-DM, where more than $25 \%$ of DM patients given treatment is due to diabetic foot [6].

Diabetic wounds easy to cause complications such as infection due to bacterial invasion. Hyperglycemic condition is an optimal place for bacterial growth, and it inhibits wound healing process [7]. Deficiency in diabetic wound 
healing process is caused by several factors such as decreased or impaired growth factor production, angiogenic response, macrophage function, collagen accumulation, epidermal barrier function, quantity of granulation tissue, keratinocytes and fibroblast migration and proliferation, number of epidermal nerves, bone healing, and balance between the accumulation of extracellular matrix components and their remodelling by matrix metalloproteinase [8].

Using plants as raw materials for treatment is still on going until now because it has relatively small side effects and is cheaper than synthetic medicine [9]. In Indonesia, there are approximately 9,600 species of plants that have been used by 400 ethnic varieties for maintenance of health and treatment of various diseases [10].

Because there are still many natural resources that can be used in Indonesia as an alternative treatment, this journal will discuss natural remedies that can be used as a treatment for diabetic wounds which have been proven its pharmacological activity in accelerating diabetic wound healing through several types of research.

\section{METHOD}

\section{Excision wound model}

The animals that usually used for research were Sprague-Dawley rats, Wistar rats, and mice (Mus musculus Albinus) and induced with streptozotocin to make them diabetes. The blood glucose level was measured, and the animals were divided into several groups. Normally, the subject groups consisted of normal control group, normal experimental group, normal positive control group, diabetic control group, diabetic experimental group, and diabetic positive control group. Then, they were anesthetized, and excision wounds were made to take full thickness skin. The experiments were conducted by applying samples topically into the wounds for several days, and percentage wound closure was calculated. Sometimes, the regenerated tissue could be taken, and histopathology of the skin was checked using several staining methods depending on the purpose $[13,18,23,24,28]$.

\section{Antimicrobial activity}

Staphylococcus aureus and Pseudomonas aeruginosa were the organisms that usually appeared in diabetic wound. The bacterial colonies were grown on agar nutrient and Mac Conkey media. Then, antimicrobial activity can be assessed by determining Minimum Inhibitory Concentration (MIC), and Minimum Bactericidal Concentration (MBC) using natural remedies extract added to the media [16].

\section{Dead space wound models}

Dead space wounds were inflicted by implanting sterile cotton pellets on the surface of each rat. The rats were divided into four groups (controls, control with sample, diabetic controls, and diabetic experimental rats). After several days, cotton pellets were carefully removed, and amount of hydroxyproline was measured, histopathology study was also conducted [28].

\section{Clinical tests}

The severe clinical study used diabetic patients with ulcer as a subject. The endpoint of the tests could be measured in several ways, but natural remedies were added in dressing to cover the wounds. First, after wound dressing, the wounds were all reconstructed by split-thickness skin graft or primary closure and had percentage change in wound size as an endpoint [20]. 
Second, the experiment used Quasi-Experiment Design with one design pre-test and post-test group approach. This study compared before and after using natural remedies in modern dressing as a treatment [31, 32].

\section{RESULT AND DISCUSSION}

\section{Natural Remedies that can be Used for Treatment of Diabetic Wounds}

\section{Andredera cordifolia}

Anredera cordifolia (Ten.) Steenis or Binahong has many benefits for curing various kinds of mild or severe diseases, including as a wound medicine [11]. A. cordifolia grows until 4 meters, has soft cylindrical trunk and in the axillary of the leaf, there are coarsely textured tubers [12]. All parts of A. cordifolia can be beneficially ranging from roots, stems, leaves, tubers, and flowers [12].

A. cordifolia leaves contain polar, semi-polar, and non-polar compounds used in wound healing processes such as tannins, saponins, alkaloids, steroids, triterpenoids, flavonoids, and essential oils [13]. A. cordifolia from Basellaceae family affects accelerating wound healing process from the effect to the skin proliferation. Also, its ethanolic extract could accelerate wound closing process on diabetic wounds [13]. Ascorbic acid in this plant is important to activate propyl hydroxylase enzymes that support the hydroxylation stage in the collagen formation and can accelerate wound healing process [11].

In addition, $A$. cordioflia plants also have antibacterial activity [14] which can help accelerate diabetic wound healing process and prevent subsequent infections. Activity of A. cordifolia leaf extracts in inhibiting bacterial growth takes place by the mechanism of inhibition of cell wall synthesis, cell membrane function, protein synthesis, and bacterial cell growth[15]. In further research, A.cordifolia extracts have activity against Staphylococcus aureus and Pseudomonas aeruginosa in diabetic foot ulcer patients [16].

\section{Centella asiatica}

Centella asiatica or pegagan from the Umbelliferae family is often used to accelerate wound healing [17]. In some studies, topical application of C.asiatica herbs in diabetic wounds can increase the speed of diabetic wound healing process [18]. C.asiatica contains asiaticosides which can increase collagen synthesis; its water extract also can improve reepithelization from corneal epithelium during wound healing process, C.asiatica stimulates fibroblast proliferation, reduces metalloproteinase activity that is resulting in rapid wound contraction [19].

Other studies also explained that the cream of $C$. asiatica is safe and can be used as a wound dressing alternative in diabetic patients who are contraindicated against hydrocolloid fiber wound dressing [20]. C. asiatica extracts have bacteriostatic and bactericidal activity against Staphylococcus aures and Pseudomonas aeruginosa from diabetic foot ulcer patients [16], so it can accelerate diabetic wound healing.

\section{Curcuma longa}

Turmeric (Curcuma longa L.) is a medicinal plant from the Zingiberaceae family which is characterized by long lifespan and tall trees [21]. Part of the plant that can be used is rhizome that is oval and short branched [21].

Curcumin is the most active component of turmeric and has potential as a treatment agent for diabetes and its complications suffered by diabetic patients [22] such as diabetic wounds. Curcumin can increase collagen in the 
treatment of diabetic wounds and accelerate wound healing process [23]. Local application of turmeric powder can specifically heal wounds due to increasing reepithelization in diabetic patients [24]. Other studies have shown that turmeric hydrocolloids can overcome infections and shorter inflammatory phases of diabetic wounds because it accelerates reepithelization, cell proliferation, and collagen synthesis [7].

\section{Carica papaya}

Papaya (Carica papaya L., Caricaceae) is a tree that grows in tropical regions around the world with fruits available throughout the year [25]. Papaya tree is a tall tree and grows rapidly with a height of 7-8 $\mathrm{m}$ and has rod diameter of $20 \mathrm{~cm}$ [25]. Papaya has two bioactive components such as papain and chymopapain, as well as other components such as alkaloids, flavonoids, and phenol components where all of these are used as a treatment of various diseases [26].

Papaya latex can increase epithelization speed in wound healing process [27]. Papaya fruit extracts if applied topically can accelerate wound healing by increasing the rate of collagen growth, granulation tissue proliferation and wound contraction in diabetic wounds [28]. Papaya fruits water extracts accelerate wound closure due to rapid epithelization and increased amount of granulation tissue in the wounds [29].

\section{Honey}

From ancient times, honey is a very popular food and can be used as a medicine because it contains many minerals such as sodium, calcium, magnesium, aluminum, iron, phosphorus, potassium, and various vitamins [30].

Honey has effect to help healing process of gangrene wound in diabetes patients [31]. It is used as an alternative therapy because of hydrogen peroxide content that serves as antibacterial, antiinflammatory, and regeneration tissue agent [30]. In addition, honey also serves as an antioxidant that produces flavonoids and can be functioned as an antiinflammatory, oxidative reactions inhibitors, and damaged cells regeneration [30].

Modern wound dressing method using honey can accelerate diabetic wound healing process because it accelerates growth of granulation tissue, has high osmolarity level so it can inhibit bacterial growth, creates moisture environment which can be absorbed properly to the skin [32], and also stimulates angiogenesis, granulation, and epithelization [33].

\section{CONCLUSION}

Diabetic patients are at high risk for foot ulcers leading to amputations. Diabetic wound healing can be accelerated using natural remedies such as Andredera cordifolia, Centella asiatica, Curcuma longa, Carica papaya and honey using various methods in rats, mice, or human.

\section{ACKNOWLEDGMENT}

The author expresses gratitude to the preceptor for criticism, suggestions, and willingness in reviewing this article.

\section{REFERENCES}

[1] Sujono, T.A., \& Sutrisna, E.M. (2010). Pengaruh lama praperlakuan flavonoid rutin terhadap efek hipoglikemik toblutamid pada tikus jantan yang diinduksi aloksan. Jurnal Penelitian Sains \& Teknologi, 11 (2), 91-99. 
[2] Sruthi, T., Satyavati, D., Upendar, K., \& Kumar, C.P. (2014). Antidiabetic activity and anti-oxidant activity of NIDDWIN, a polyherbal formulation in alloxan-induced diabetic rats. International Journal of Pharmacy and Pharmaceutical Sciences, 6 (2), 273-277.

[3] Adnan, M., Mulyati, T., \& Isworo, J.T. (2013). Hubungan indeks massa tubuh (IMT) dengan kadar gula darah penderita diabetes mellitus (DM) tipe 2 rawat jalan di RS Tugurejo Semarang. Jurnal Gizi Universitas Muhammadiyah Semarang, 2 (1), 1824.

[4] Pasaribu, F., Sitorus, P., \& Bahri, S. (2012). Uji ekstrak etanol kulit buah manggis (Garcinia mangostana L.) terhadap penurunan kadar glukosa darah. Journal of Pharmaceutics and Pharmacology, 1 (1), 1-8.

[5] Kusumaningrum, N.S.D., \& Asriningati, R. (2016). Identifikasi risiko diabetic foot ulcer (DFU) pada pasien dengan diabetes mellitus. Journal Luka Indonesia 2 (1), 58-63.

[6] Sunaryo, T., \& Sudiro (2014). Pengaruh senam diabetik terhadap penurunan resiko ulkus kaki diabetik pada pasien DM tipe 2 di perkumpulan diabetik. Jurnal Terpadu Ilmu Kesehatan 3 (1), 99105.

[7] Doddy, Y.P., Mardiyono, M., \& Kusuma, H. (2017). Studi kasus uji pra klinik perawatan ulkus kaki diabetik dengan topikal hidrokoloid kunyit. Jurnal Kebidanan dan Keperawatan 13 (2), 111-119.

[8] Brem, H., \& Canic, M.T. (2007). Cellular and molecular basis of wound healing in diabetes. The Journal of Clinical Investigation 117 (5), 1219-1222.
[9] Takoy, D.M., Linda, R., \& Lovadi, I. (2013). Tumbuhan berkhasiat obat Suku Dayak Seberuang di Kawasan Hutan Desa Ensabang Kecamatan Sepauk Kabupaten Sintang. Jurnal Protobiont 2 (3), 122-128.

[10] Wiwaha, G., Jasaputra, S.N.B.D.K., Yunivita, V., Muchtar, E. (2012). Tinjauan etnofarmakologi tumbuhan obat/ramuan obat tradisional untuk pengobatan dislipidemi yang menjadi kearifan lokal di Provinsi Jawa Barat.Jurnal Medika Planta 2 (1), 111-119.

[11] Ariani, S., Loho, L., \& Durry, M.F. (2013). Khasiat daun binahong (Anredera cordifolia (Ten.) Steenis) terhadap pembentukan jaringan granulasi dan reepitelisasi penyembuhan luka terbuka kulit kelinci. Jurnal e-Biomedik 1 (2), 914919.

[12] Karouw, S., \& Balitka, R.B. (2009). Binahong (Anredera cordifolia) sebagai obat. Warta Penelitian dan Pengembangan Tanaman Industri 15 (1), 3-5.

[13] Kintoko, Karimatulhajj, H., Elfasyari, T.Y., Ihsan, E.A., Putra, T.A., Hariadi, P., Ariani, C., \& Nurkhasanah (2017). Pengaruh kondisi diabetes pada pemberian topikal fraksi daun binahong dalam proses penyembuhan luka. Tradicional Medicine Journal 22 (2), 103-110.

[14] Darsana, I.G.O., Besung, I.N.K., \& Mahatmi, H. (2012). Potensi daun binahong (Anredera cordifolia (Tenore) Steenis) dalam menghambat pertumbuhan bakteri Escherichia coli secara In Vitro. Indonesia Medicus Veterinus 1 (3), 337-351. 
[15] Ainurrochmah, A., Ratnasari, E., \& Lisdiana, L. (2013). . Efektivitas ektak daun binahong (Anredera cordifolia) terhadap penghambatan pertumbuhan bakteri Shigella flexneri dengan metode sumuran. LenteraBio 2 (3), 233-237.

[16] Sutrisno, E., Adnyana, I.K., Sukandar, E.Y., Fidrianny, I., \& Lestari, T. (2014). Kajian aktivitas penyembuhan luka dan antibakteri binahong (Anredera cordifolia (Ten.) Steenis), pegagan (Centella asiatica (L.) Urban) serta kombinasinya terhadap bakteri Staphylococcus aureus dan Pseudomonas aeruginosa dari pasien luka kaki diabetes. Jurnal Ilmu-Ilmu Hayati dan Fisik 16 (2), 78-82.

[17] Chaucan, P.K., Pandey I.P., \& Dhatwalia, V.K. (2010). Evaluation of the anti-diabetic effect of ethanolic and methanolic extracts of Centella asiatica leaves extact on alloxan induced diabetic rats. Advances in Biological Research 4 (1), 27-30.

[18] Ngalansom, J., Suttitum, T., Jirakulsomchok, D., \& Puapairoj, A. (2008). Effects of Centella asiatica Linn. Leaves and Garcinia mangostana Linn. Hull on the healing of dermal wounds in diabetic rats. Srinagarind Medical Journal 23 (4), 302-407.

[19] Bylka, W., Awizen, P.Z., Sroka, E.S., Pazdrowksa., \& Brzezinska, M. (2014). Centella asiatica in dermatology: an overview. Phytotherapy Research 28, 11171124.

[20] Kuo, Y.S., Chien, H.F., \& Lu, W. (2012). Plectranthus amoinicus and Centella asiatica cream for the treatment of diabetic foot ulcers. Evidence-Based Complementary and Alternative Medicine, 1-9.
[21] Nisar, T., Iqbal, N., Raza, A., Safdar, M., Iftikhar, F., \& Waheed, M. (2015). Tumeric: a promising spice for phytochemical and antimicrobial activities. American-Eurasian Journal of Agriculture \& Environmental Sciences 15 (7), 12781288.

[22] Zhang, D.W., Fu, M., Gao, S.H., \& Liu, J.L. (2013). Cucumin and diabetes: a systematic review. Evidence-Based Complementary and Alternative Medicine, 1-16.

[23] Mohammadi, M.R., Rabbani, S., Bahrami, S.H., Joghataei, M.T., \& Moayer, F. (2016). Antibacterial performance and in vivo diabetic wound healing of curcumin loaded gum tragacanth/poly ( $\varepsilon$-caprolactone) electrospun nanofibers. Materials Science and Engineering 69, 11831191.

[24] Wientarsih, I., Winarsih, W., \& Sutardi, L.N. (2013). The efficacy and safety of topical gel formulation of n-hexane fraction of Curcuma longa in wound healing of hypergycemic mice. Jurnal Veteriner 14 (1), 19-23.

[25] Adaneye, A.A., \& Olagunju, J.A. (2009). Preliminary hypoglycemic and hypolipidemic activities of the aqueous seed extract of Carica papaya Linn. in Wistar rats. Biology and Medicine 1 (1), 1-10.

[26] Anaga, A.O., \& Onehi, E.V. (2010). Antinociceptive and antiinflammatory effects of the methanol seed extract of Carica papaya in mice and rats. African Journal of Pharmacy and Pharmacology 4 (4), 140-144.

[27] Gurung, S., \& Basnet, N.S. (2009). Wound healing properties of Carica papaya latex: In vivo evaluation in mice burn model. Journal of Ethnopharmacology 121, 338-341. 
[28] Nayak, B.S., Pereira, L.P., \& Maharaj, D. (2007). Wound healing activity of Carica papaya L. in experimentally induced diabetic rats. Indian Journal of Experimental Biology 45, 739-743.

[29] Alam, G., Singh, M.P., \& Singh, A. (2011). Wound healing potential of some medicinal plants. International Journal of Pharmaceutical Sciences Review and Research 9 (1), 136-145.

[30] Aftria, M.P. (2014). Honey as topical treatment for diabetic foot ulcers. Journal Majority 3 (7), 81-87.
[31] Nabhani, \& Widiyastuti, Y. (2017). Pengaruh madu terhadap proses penyembuhan luka gangren pada pasien diabetes mellitus. Profesional Islam Media Publikasi Penelitian 15 (1), 65-69.

[32] Siswantoro, E. (2017). Efektivitas perawatan luka diabetik metode modern dressing menggunakan madu terhadap proses penyembuhan luka. Jurnal Keperawatan \& Kebidanan, 112-116.

[33] Al-Waili, N.S., Salom, K., \& AlGhamdi, A.A. (2011). Honey for wound healing, ulcers, and burns: data supporting its use in clinical practice. The Scientific World Journal 11, 766-787.

How to cited this article :

Andranilla, R.K., Susilawati, Y., 2018. Review of Natural Remedies for Accelerate Diabetic Wound Healing. J. Trop.Pharm. Chem. 4(3); 147-153. 